\title{
SEKOLAH MENENGAH KEJURUAN DESAIN ANIMASI \\ DI BANJARBARU
}

\author{
Julia Rizky Amalia \\ Program Studi Teknik Arsitektur Fakultas Teknik Universitas Lambung Mangkurat \\ h1b113054@ulm.ac.id
}

\section{Prima Widia Wastuty}

Program Studi Teknik Arsitektur Fakultas Teknik Universitas Lambung Mangkurat

emaildosen@ulm.ac.id

\begin{abstract}
ABSTRAK
Animasi merupakan subsektor industri kreatif yang memiliki peluang bisnis menjanjikan dan dapat menyerap tenaga kerja kreatif dengan jumlah besar. Semakin banyak kreator animasi di Indonesia menunjukkan meningkatnya permintaan terhadap perfilman animasi, sayangnya kualitas animator belum mampu bersaing secara Internasional karena infrastruktur yang kurang memadai dan edukasi yang rendah. Pemerintah membantu mendorong perkembangan industri animasi dengan membuka pendidikan SMK, dimana SMK Animasi dapat menjadi wadah khusus kegiatan pembelajaran dalam bidang teknologi animasi, bertujuan untuk meningkatkan Sumber Daya Manusia (SDM). Tema Interactive Space menawarkan penyelesaian masalah SMK animasi yang mempunyai wadah interaktif. Cara yang dipakai yaitu menciptakan tempat untuk bertukar ide-ide yang saling menstimulasi. Seperti ruang santai yang bisa menjadi ruang kolaboratif untuk berdiskusi dan bersantai.
\end{abstract}

Kata kunci: Animasi, Interactive, Space,SDM, SMK, Ruang Kolaboratif.

\section{ABSTRACT}

Animation is a sub-sector of the creative industry that has promising business opportunities and is able to absorb a lot of creative labor. The increasing number of animation creators in Indonesia shows the increasing demand for animated films, unfortunately the quality of animators has not been able to compete internationally due to inadequate infrastructure and low education. The government also encourages the development of the animation industry by opening vocational education, where the Animation Vocational School can become a special forum for learning activities in the field of animation technology which aims to improve Human Resources (HR). The Interactive Space theme offers problem-solving for Animated Vocational Schools which have an interactive platform. The method used is to create a place to stimulate ideas. Like a waiting room which can be a collaborative space for discussion and relaxation.

Keywords: Animation, Interactive, Space, Human Resources, Vocational School, Collaborative Space. 


\section{PENDAHULUAN}

Industri animasi Indonesia semakin berkembang, meski pelan namun pasti. Animasi tidak hanya menghasilkan produk berupa film, tetapi sudah mempunyai produk turunan berupa mainan, komik, permainan video (video game), dan barang niaga lainnya. Animasi juga menjadi salah satu subsektor industri kreatif, karena peluang bisnisnya yang menjanjikan dan mampu menyerap tenaga kerja kreatif dalam jumlah besar. Industri animasi secara global selalu dikaitkan dengan industri permainan (game). Biaya produksi untuk film animasi sendiri terbilang besar. Dalam produksi film animasi 2D, biasanya $70-80 \%$ dari total ongkos produksi merupakan gaji pekerja, sedangkan untuk produksi animasi 3D yang peran utamanya sudah berganti ke software dan hardware, gaji pekerja menghabiskan sebesar $60 \%$ total ongkos produksi.

Keterampilan yang diperlukan untuk menguasai sektor animasi sebenarnya dimiliki oleh masyarakat muda di Indonesia, tetapi masalah infrastruktur yang kurang memadai dan edukasi yang seadanya membuat kebanyakan orang Indonesia kandas dalam usahanya menjalankan bisnis sektor animasi ini. Kualitas animator Indonesia yang harus mampu bersaing Internasional menjadi salah satu faktor penentu keberhasilan dan perkembangan industri animasi. Semakin banyaknya produsen animasi di Indonesia menunjukkan meningkatnya permintaan terhadap perfilman animasi.

Di Indonesia belum banyak muncul IP (Intellectual Property) untuk animasi karena beberapa faktor, seperti belum tumbuhnya bisnis animasi untuk didistribusikan di Indonesia seperti di negara-negara lain. Perlu adanya kerja sama antara pemerintah dengan pelaku industri, pemerintah dengan pemerintah (dinas-dinas terkait), pemerintah dan jalur distribusi animasinya, dan juga kerjasama antar pelaku industri itu sendiri. Pendidikan menjadi salah satu sarana yang menyediakan sumber daya kreatif di bidang animasi. Pemerintah membantu mendorong perkembangan industri animasi dengan cara membuka pendidikan setara SMA, yaitu SMK.

Perlunya Sekolah Menengah Kejuruan Teknologi Desain Animasi yang mewadahi kegiatan pembelajaran khususnya untuk Kota Banjarbaru dalam bidang teknologi animasi, bertujuan untuk meningkatkan Sumber Daya Manusia (SDM). Semakin tinggi kualitas keahlian para pekerja di bidang animasi semakin tinggi pula kualitas produk animasi yang akan dihasilkan. Sayangnya lembaga yang mendukung dalam peningkatan kualitas tersebut masih minim adanya. Sekolah Menengah Kejuruan yang memiliki jurusan di teknologi animasi hanya berjumlah 9 sekolah di Banjarbaru. Dengan jumlah jurusan menjurus animasi hanya 1 jurusan di SMKN 1 Banjarbaru bernama Desain Komunikasi Visual (DKV), dan paling banyak adalah teknologi digital seperti komputer jaringan dan multimedia berjumlah 8 SMK.

Tabel 1. Data SMK di Banjarbaru

\begin{tabular}{|c|c|c|c|}
\hline No & SMK & STATUS & $\begin{array}{l}\text { KOMPETENSI } \\
\text { KEAHLIAN }\end{array}$ \\
\hline 1 & SMKN 1 & NEGERI & 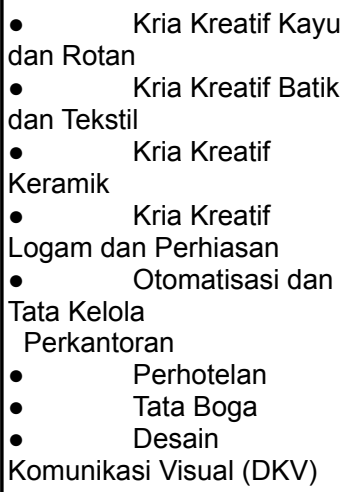 \\
\hline 2 & SMKN 2 & NEGERI & 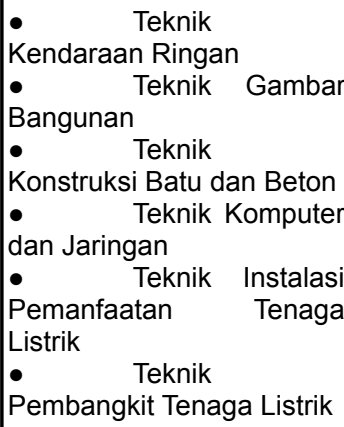 \\
\hline
\end{tabular}




\begin{tabular}{|c|c|c|c|}
\hline & & & • \\
\hline 3 & SMKN 3 & NEGERI & 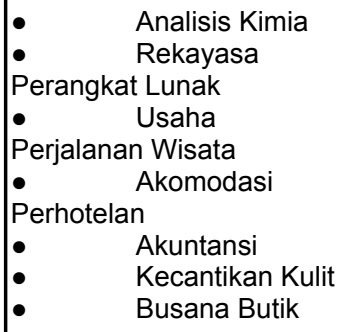 \\
\hline 4 & SMKN 4 & NEGERI & $\begin{array}{ll}\bullet & \text { Multimedia } \\
\bullet & \text { Pemasaran } \\
\text { Motor } & \text { Teknik Sepeda }\end{array}$ \\
\hline 5 & $\begin{array}{l}\text { SMKS } \\
\text { BHAKTI } \\
\text { BANGSA }\end{array}$ & SWASTA & $\begin{array}{ll}\bullet & \text { Teknik Alat Berat } \\
\bullet & \text { Teknik } \\
\text { Kendaraan Ringan } & \\
\bullet & \text { Teknik Sepeda } \\
\text { Motor } \quad & \\
\bullet \quad & \text { Teknik } \\
\text { Multimedia } & \end{array}$ \\
\hline 6 & $\begin{array}{l}\text { SMKS YPK } \\
\text { BANJAR-BA } \\
\text { RU }\end{array}$ & SWASTA & 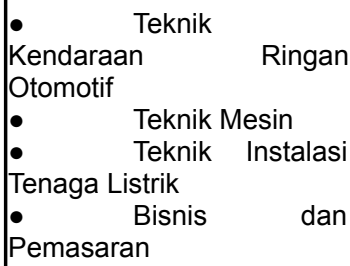 \\
\hline 7 & $\begin{array}{l}\text { SMKS } \\
\text { TELKOM } \\
\text { SANDHY } \\
\text { PUTRA } \\
\text { BANJAR-BA } \\
\text { RU }\end{array}$ & SWASTA & \begin{tabular}{|ll}
$\bullet$ & Teknik Jaringan \\
Akses & Telekomunikasi \\
$\bullet$ & Teknik Komputer \\
Jaringan & \\
$\bullet$ & Multimedia \\
- & Rekayasa \\
Perangkat Lunak
\end{tabular} \\
\hline 8 & $\begin{array}{l}\text { SMKS } \\
\text { SABUMI } \\
\text { BANJAR-BA } \\
\text { RU }\end{array}$ & SWASTA & 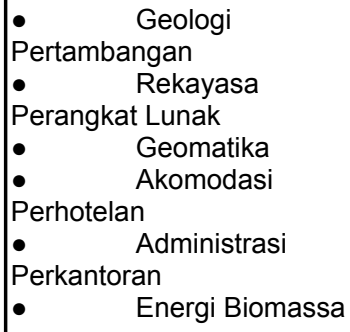 \\
\hline 9 & $\begin{array}{l}\text { SMK } \\
\text { GARUDA } \\
\text { MAHA-DHIK } \\
\text { A }\end{array}$ & SWASTA & 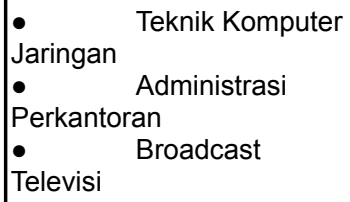 \\
\hline 10 & $\begin{array}{l}\text { SMKS } \\
\text { KOMPU-TE } \\
R \text { MANDIRI } \\
\text { BANJAR-BA } \\
\text { RU }\end{array}$ & SWASTA & 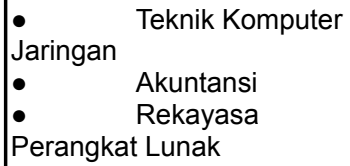 \\
\hline
\end{tabular}

\begin{tabular}{|l|l|l|ll|}
\hline 11 & SMKS & SWASTA & $\bullet$ & Keperawatan \\
& CAHAYA & & & Teknik Komputer \\
& $\begin{array}{l}\text { INSAN } \\
\text { BANAR-BA }\end{array}$ & & Jaringan & \\
\hline
\end{tabular}

Tujuan desain SMK Teknologi Desain Animasi yang bisa menjadi pelopor utama peningkatan pendidikan animasi dan sumber dayanya di Kalsel khususnya Banjarbaru, yaitu dengan memiliki workshop studio animasi yang memadai setidaknya sesuai dengan Kerangka Kualifikasi Nasional Indonesia (KKNI) (RI M. K., 2014). Oleh karena itu dapat disimpulkan bahwa rancangan desain sekolah pelopor di bidang teknologi desain animasi di Banjarbaru adalah untuk meningkatkan kualitas sumber daya manusia dibidang industri animasi.

\section{PERMASALAHAN}

Dari hasil kajian yang didapatkan bisa dirumuskan bahwa permasalahan arsitektural yang akan diangkat adalah Bagaimana rancangan sekolah kejuruan animasi di Banjarbaru Kalsel yang dapat menciptakan wadah interaktif untuk menstimulasi belajar kreatif. Wadah interaktif yang dimaksud bisa berupa benda fisik, sebuah ruang di bangunan, ataupun sebuah bagian di bangunan. Cara yang digunakan dalam penyelesaian masalah yaitu wadah interaktif yang membuat pelaku berinteraksi sesama pelaku dan lingkungan.

Interactive space merupakan sebuah lingkungan publik dimana orang bisa ikut berpartisipasi aktif di dalamnya, misalkan sebuah taman dengan permainan animasi, atau sebuah dinding dengan permukaan sentuh seperti layar monitor, dan lain-lain.

\section{TINJAUAN PUSTAKA}

Pengertian Sekolah Menengah Kejuruan Desain Animasi yaitu:

- Sekolah Menengah Kejuruan, menurut (UU Nomor 20 pasal 18 ayat [3], 2013) adalah salah satu bentuk satuan 


pendidikan formal $\begin{array}{r}\text { yang } \\ \text { menyelenggarakan }\end{array}$ pendidikan
kejuruan pada jenjang pendidikan
menengah sebagai lanjutan dari
SMP/MTs atau bentuk lain yang
sederajat atau lanjutan dari hasil
belajar yang diakui sama/setara
SMP/MTs.

- Desain, menurut JB Reswick (Reswick, 1966) adalah suatu aktivitas kreatif yang melibatkan penciptaan sesuatu yang baru dan berguna yang belum ada sebelumnya.

- Animasi, menurut Jean Ann Wright (Wright, 2014), adalah usaha manusia dalam menggambarkan pergerakan makhluk hidup maupun benda melalui sebuah media dapat dinamakan menganimasikan (bahasa Inggris: "animate") yang asal katanya dari bahasa Latin "animare", yang artinya menghidupkan, mengisi dengan kehidupan, membuat menjadi hidup atau memberikan nyawa.

Jadi Sekolah Menengah Kejuruan Desain Animasi di Banjarbaru adalah sekolah kejuruan kreatif yang mewadahi pembelajaran animasi.

\section{A. Batasan dan Ruang Lingkup}

Batasan Sekolah Menengah Kejuruan Desain Animasi mewadahi aktivitas pembuatan produksi animasi. Animasi yang dipelajari dikhususkan untuk animasi 3 dimensi (3D), dengan pembelajaran umum di animasi 2 dimensi (2D) dan stop-motion.

\section{B. Deskripsi Pelaku dan Aktivitas}

Secara umum pengguna Sekolah Menengah Kejuruan Desain Animasi yaitu: Siswa dan Guru adalah pengguna bangunan dan fasilitas-fasilitas yang disediakan. Pengelola atau Pegawai (satpam dan petugas kebersihan) adalah orang yang bekerja untuk mengurus kebutuhan dan kelancaran kegiatan di lingkungan sekolah, dan menjaga keamanan lingkungan sekolah.
Aktivitas pengelola adalah mengelola, menjaga kebersihan dan keamanan di lingkungan SMK Desain Animasi. Aktivitas Siswa adalah belajar, mendapat pelajaran, berkegiatan diskusi bersama terhadap animasi, dan menikmati fasilitas-fasilitas yang disediakan. Aktivitas pengajar adalah mengajarkan dan membantu siswa dalam mengembangkan potensi dan kreativitasnya dalam beranimasi.

\section{Tinjauan Konsep Interactive Space \\ Tema dari SMK Desain Animasi ini} adalah Interactive Space, yaitu suatu ruang, bagian, atau wilayah di bangunan yang menggambarkan atau memiliki animasi yang bisa berinteraksi dengan manusia. Untuk mencapai itu maka dibutuhkan ruang yang interaktif. Menurut seorang pakar teknologi dan komunikasi interaktif, Ester Dyson mengungkapkan dua pengertian dari interaktif:

- Berinteraksi dengan media televisi, CD, komputer, internet, dan telepon.

- Berinteraksi dengan sesama manusia lain. Berinteraksi dengan manusia merupakan tingkatan yang lebih tinggi daripada dengan media karena melibatkan komunikasi dua arah dan mampu saling memberikan penilaian.

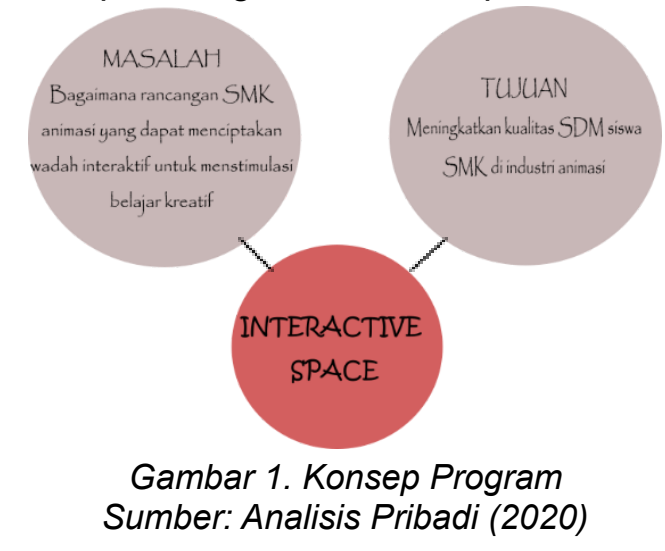

Hal ini diterapkan dalam desain interior dengan media teknologi animasi yang dapat disesuaikan dengan tema didalamnya. Sehingga untuk mewujudkan wadah interaktif dalam bangunan tersebut dapat dengan menggunakan metode simulasi produk-produk animasi. Teknologi ini 
menawarkan simulasi animasi yang menarik sehingga terjadilah interaksi antara pelaku dengan bangunan/animasi. Sehingga dicapailah sekolah animasi dengan wadah interaktif untuk belajar kreatif.

\section{Konsep Programatik}

Tema Interactive Space menawarkan penyelesaian masalah SMK animasi yang mempunyai wadah interaktif. Cara yang dipakai yaitu menciptakan tempat untuk bertukar ide-ide yang saling menstimulasi. Seperti ruang santai yang bisa menjadi ruang kolaboratif untuk berdiskusi dan bersantai. melalui :

Konsep interactive space diwujudkan

- Discovery: ruang dan perabotnya memungkinkan pelaku berinteraksi dengan mengalaminya (discover by experience).

- Collaboration: orang-orang bekerja sama dalam saling berinteraksi, diterapkan sebagai ruang diskusi bersama.

- Creativity: ruang dan perabotnya membantu dalam stimulasi ide kreatif dan inovasi baru.

- Interaction: ruang dan teknologi/ perabotnya bisa berinteraksi secara intuitif kepada pelaku

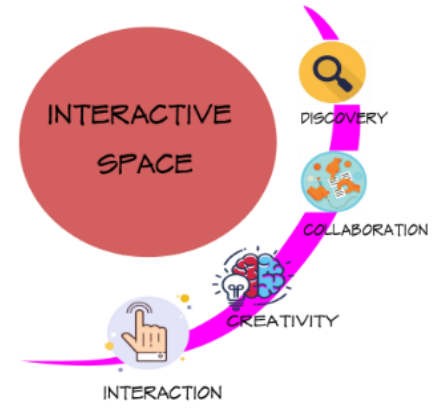

Gambar 2. Konsep Programatik Sumber: Analisis Penulis (2020)

\section{Konsep Rancangan}

\section{a. Konsep Discovery}

Bentuk merupakan hal pertama yang akan dilihat, oleh karena itu bentukan yang unik dan menarik akan sangat baik untuk diterapkan. Konsep bentukan berdasarkan analisis zonasi ruang.

Bentukan awal terinspirasi dari bentukan organik playground yang berdasar dari bentuk lingkaran. Pemilihan bentukan yang melingkar didasari oleh kreativitas yang muncul seringkali secara organis dari bentuk-bentuk alam yang kebanyakan lengkung dan lingkaran, sehingga bentukan yang melengkung dan tidak terlalu bersudut baik untuk bentukan bangunan

\section{b. Konsep Collaboration}

Konsep kolaborasi yang dimaksud adalah sebuah ruang diskusi, tempat pelaku berinteraksi sesama pelaku dalam memecahkan atau menemukan ide baru. Ruang diskusi ini bisa berfungsi fleksibel dengan ruang konsep lainnya ataupun berdiri sendiri.

Ruang diskusi berfungsi juga sebagai ruang santai dan cafeteria, merupakan ruang pertama yang akan ditemui saat masuk ke dalam bangunan. Sehingga ruang ini akan ditempatkan di lantai dasar, dan akan menjadi salah satu wadah interaktif utama yang bersifat publik. Pencahayaan diusahakan dibuat alami, sehingga dinding ruang dibuat dengan material setengah kaca. Kaca ini berfungsi sebgaai layar yang menunjukkan kegiatan didalamnya. Tema warna diterapkan dengan warna netral dingin seperti abu-abu, yang kemudian dipadu dengan warna primer untuk perabot sebagai titik fokus di interiornya.

\section{c. Konsep Creativity}

Ruang dan perabot dapat membantu dalam stimulasi ide kreatif dan inovasi baru. Diterapkan di ruang perpustakaan, dimana perabotnya diusahakan multifungsi, untuk memacu berpikir kreatif. 


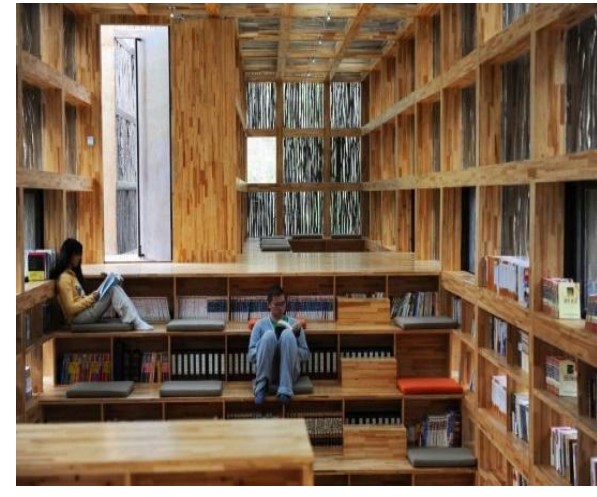

Gambar 3. Desain awal ruang perpustakaan

Ruang perpustakaan merupakan salah satu standar ruang yang diperlukan di SMK, sebagai tempat koleksi referensi informasi yang diperlukan siswa untuk belajar dan beranimasi. Sehingga ruang ini harus nyaman dipakai siswa, dengan perabot yang bisa multifungsi sebagai penyimpanan buku dan bersantai siswa. Aksen warna coklat kayu hingga hitam-abu mengikuti warna material perabot ruang.

\section{d. Konsep Interaction}

Ruang dan teknologi/perabotnya bisa berinteraksi secara intuitif kepada pelaku (siswa).

\section{PEMBAHASAN}

\section{A. Lokasi}

Dalam menentukan lokasi dan tapak untuk perencanaan Sekolah Menengah Kejuruan Teknologi Desain Animasi Banjarbaru terdapat beberapa pertimbangan antara lain :

- Menyesuaikan dengan Peraturan Daerah Kota Banjarbaru Nomor 13 Tahun 2014 tentang Rencana Tata Ruang Wilayah Kota Banjarbaru Tahun 2014-2034. Lokasi Pusat Lingkungan (PL) yang meliputi pendidikan salah satunya terdapat di Kelurahan Guntung Manggis,
Kecamatan Landasan Ulin, Banjarbaru Selatan.

Lokasi tapak harus memiliki aksesibilitas dan berada pada kawasan pendidikan

Lokasi tapak berada di Kota Banjarbaru, tepatnya di Jl. Trikora, Kelurahan Landasan Ulin, Kecamatan Banjarbaru Selatan. Dengan lebar jalan sekitar 18 meter, dan luas lahan site sekitar 1,2 hektar.

Tabel 1. exercitation ullamco

\begin{tabular}{|l|l|l|}
\hline No & Judul & Item \\
\hline 1 & enim & ullamco \\
\hline 2 & ullamco & ullamco \\
\hline 3 & ullamco & ullamco \\
\hline
\end{tabular}

sumber : Lorem ipsum

Lorem ipsum dolor sit amet, consectetur adipisicing elit, sed do euismod tempor incididunt ut labore et dolore magna aliqua. Ut enim ad minim veniam, quis nostrud exercitation ullamco laboris nisi ut aliquip ex ea commodo consequat. Duis aute irure dolor in reprehenderit in voluptate velit esse cillum dolore eu

\section{B. Konsep Rancangan}

1. Tata Masa

Selalu awali dengan kalimat jangan dimulai dengan gambar. selalu awali dengan kalimat jangan dimulai dengan gambar.selalu awali dengan kalimat jangan dimulai dengan gambar. selalu awali dengan kalimat jangan dimulai dengan gambar.selalu awali dengan kalimat jangan dimulai dengan gambar.selalu awali dengan kalimat jangan dimulai dengan gambar.selalu awali dengan kalimat jangan dimulai dengan gambar.selalu awali dengan kalimat jangan dimulai dengan gambar. 
selalu awali dengan kalimat jangan dimulai dengan gambar.

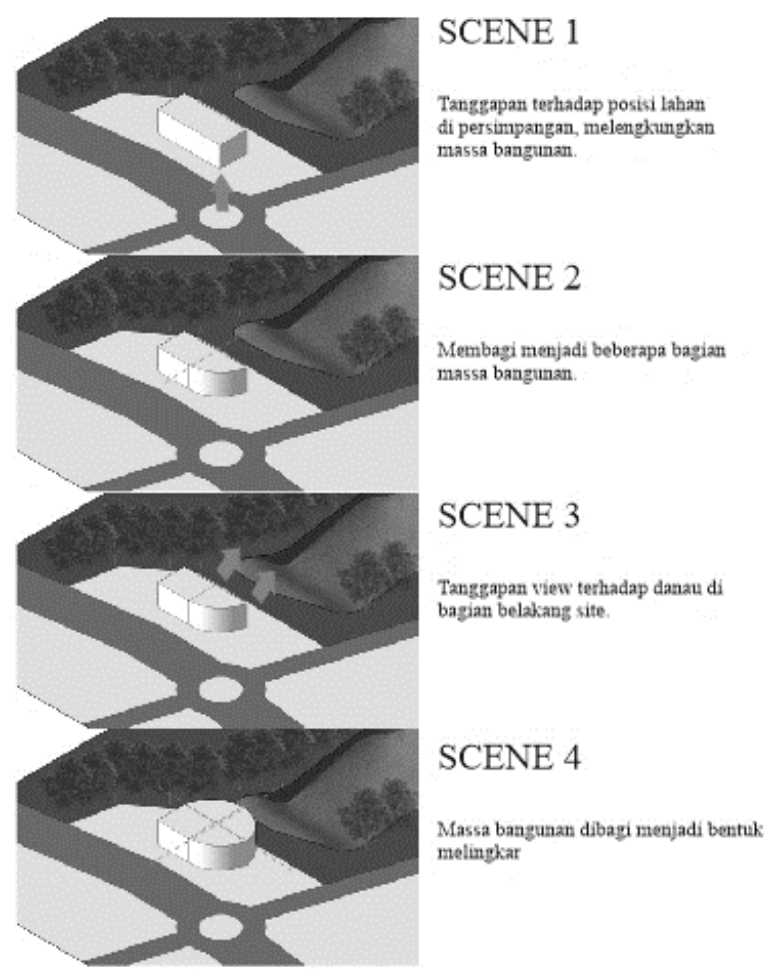

Gambar 8. Hubungan Ruang dan Fungsi Sumber: Analisis Pribadi (2020)

\section{HASIL}

Lorem ipsum dolor sit amet, consectetur adipisicing elit, sed do euismod tempor incididunt ut labore et dolore magna aliqua. Ut enim ad minim veniam, quis nostrud exercitation ullamco laboris nisi ut aliquip ex ea commodo consequat. Duis aute irure dolor in reprehenderit in voluptate velit esse cillum dolore eu Lorem ipsum dolor sit amet, consectetur adipisicing elit, sed do euismod tempor incididunt ut labore et dolore magna aliqua. Ut enim ad minim veniam, quis nostrud exercitation ullamco laboris nisi ut aliquip ex ea commodo consequat. Duis aute irure dolor in reprehenderit in voluptate velit esse cillum dolore eu

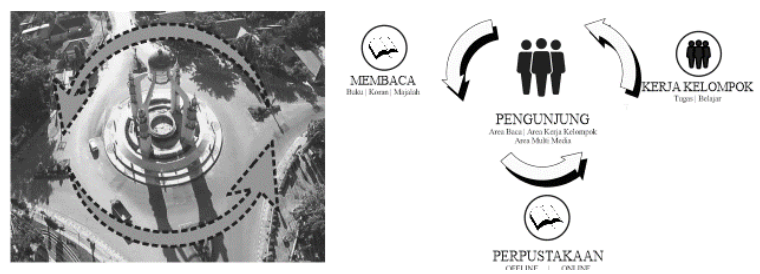

Gambar 13. Gagasan Ide Awal Sumber: Analisis Pribadi (2020)

Lorem ipsum dolor sit amet, consectetur adipisicing elit, sed do euismod tempor incididunt ut labore et dolore magna aliqua. Ut enim ad minim veniam, quis nostrud exercitation ullamco laboris nisi ut aliquip ipsum dolor sit amet, consectetur adipisicing elit, sed do euismod tempor incididunt ut labore et dolore magna aliqua. Ut enim ad minim veniam, quis nostrud exercitation ullamco laboris nisi ut aliquip ex ea commodo consequat. Duis aute irure dolor in reprehenderit in voluptate velit esse cillum dolore eu
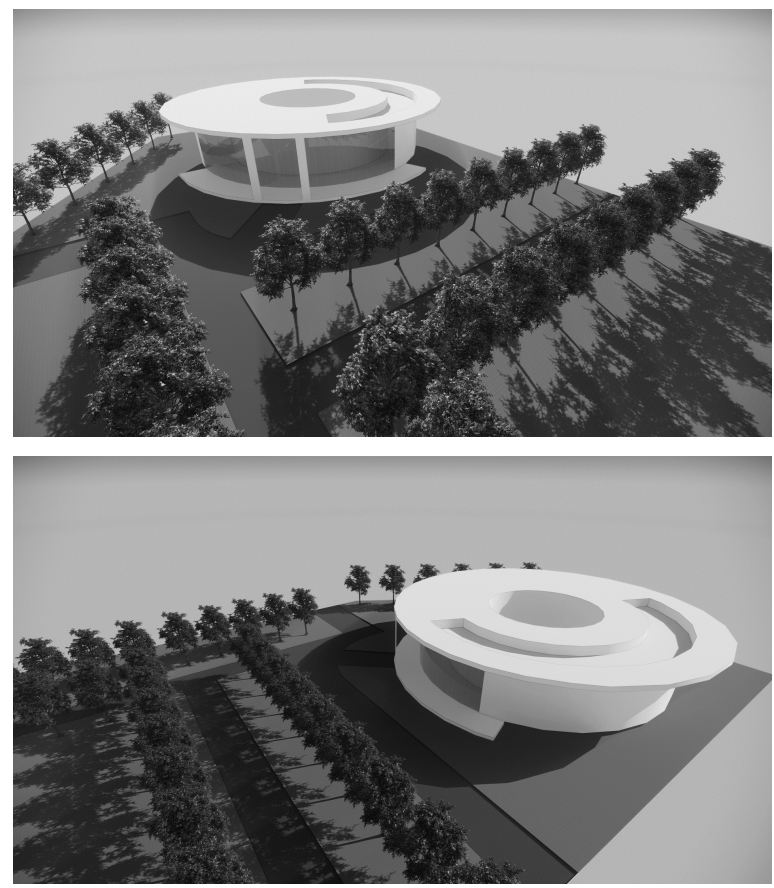

Gambar 15. Perspektif Mata Burung Sumber: Analisis Pribadi (2020) 


\section{KESIMPULAN}

Rancangan SMK Desain Animasi memiliki fungsi pendidikan dan memiliki tujuan untuk meningkatkan mutu SDM siswa SMK di bidang animasi. Animasi sendiri adalah suatu bidang industri yang memerlukan kreativitas dalam segala bidangnya. Masalah yang didapat adalah perlunya sebuah wadah interaktif untuk menstimulasi belajar kreatif. Metode yang dipakai sebagai pemecahan masalah adalah konsep interactive space.

Di dalam konsep interactive space diwujudkan dengan 4 hal utama, yaitu:

- Discovery: ruang dan perabotnya memungkinkan pelaku berinteraksi dengan mengalaminya (discover by experience).

- Collaboration: orang-orang bekerja sama dalam saling berinteraksi, diterapkan sebagai ruang diskusi bersama.

- Creativity: ruang dan perabotnya membantu dalam stimulasi ide kreatif dan inovasi baru.

- Interaction: ruang dan teknologi/ perabotnya bisa berinteraksi secara intuitif kepada pelaku.

\section{DAFTAR PUSTAKA}

Referensi Buku dan Jurnal

AAD. (2014). Task in The Advanced Architectural Design. Dwelling Typologies, 256-261.

Antoniades, Anthony C, (1990). Poetics of Architecture: Theory of Design. New York: Van NostrandReinhold.

Benny, Pispantoro (1992). Konstruksi Bangunan Gedung Bertingkat Rendah. Yogyakarta: Universitas Atma Jaya.

Broadbent, Geoffrey, (1973). Design in Architecture. London

Ching, F. D. (2000). Arsitektur Bentuk dan Susunannya. Jakarta: Erlangga.

Ernst, Neufert, (1987). Data Arsitek Jilid 1 Edisi Kedua, Jakarta: Erlangga.

Sutedjo, S.B: (1980). Peran, kesan dan Pesan Bentuk-Bentuk Arsitektur. Jakarta: Djambatan.
Wiley, Budihardjo, Eko (1996). Menuju Arsitektur Indonesia. Bandung: Alumni IKAPI.

Pribadi. (2020). Analisis Tugas, Banjarbaru: Dimas Perdana Putra.

\section{Website}

Aditya, Panca. (2010, Februari 28) Jenis-Jenis Pola Pembelajaran. Diambil kembali dari gooddesignforlife.blogspot.com/2010/02/je nis-jenis-pola-sirkulasi.html

Amy, Nur. (2011, Juni 10) Prinsip-Prinsip Membaca. Diambil kembali dari nuramy.blogspot.com/2011/06/prinsip-prins ip-membaca.html

Arsitur (2018, September). Arsitektur Metafora. Diambil kembali dari Arsitur: arsitur.com/2018/09/arsitektur-metafora-le ngkap.html

Azis, Abd. Syamsurijal. Julianti. (2012, Desmber 07) Problematika dalam pembelajaran. Diambil kembali dari jalboeghiz.blogspot.com/2012/12/problem atika-dalam-pembelajaran.html

Cornelia, Verina. (2018, November 06) News Nasional. Diambil kembali dari Kompas.som:

Kompasiana.com/verinacornelia1703/5bcf db47aeebe105a277cea7/ini-dia-3-hal-yan g-bisa-kamu-lakkan-di-perpustakaan-uajy? page $=1$

Nathanssu. (2012, Februari 17) Membaca. Diambil kembali bacacepat.com/membaca/

Prisma, Dony. (2012, Mei 28) Definisi perpustakaan Digital-Digital Library. Diambil kembali dari donyprisma.wordpress.com/2012/05028/d efinisi-perpustakaan-digital-digital-library/

Wikipedia (2020, Mei 03) Definisi Perpustakaan Digital. Diambil kembali dari id.wikipedia.org/wiki/perpustakaan_digital 